\title{
Education Attainment and Women Entrepreneurship in Uganda: A Perspective
}

\author{
Barongo Eleanor Kirahora \\ Department of Development, Peace and Conflict Studies, Kampala International University, Uganda \\ Janice D. Busingye, Ph.D. \\ College of Education, Distance and Open Learning, Kampala International University, Uganda \\ Grace Lubaale, Ph.D. \\ Department of Development, Peace and Conflict Studies, Kampala International University, Uganda
}

\begin{abstract}
This study examined the impact of education attainment on women's desire and capacity to venture into entrepreneurship in Bunyoro sub-region, Uganda. The study was guided by the Human Capital Theory, which emerged in the 1960s through the works of Theodre Schultz in 1962. The theory holds that education enhances an individual's efficiency and productivity skills, which in return increases the earnings of that individual in the labor market, as well as his/ her capacity to manage own business. The study adopted a descriptive correlation research design, primarily to determine the relationships between education attainment and women entrepreneurship in Bunyoro sub-region of Uganda. The mixed methods approach was used in data collection and 365 residents of Bunyoro participated in the study. Questionnaires were used to collect quantitative data, while key informants were interviewed for qualitative data. The study findings show that education attainment has a significant positive relationship with women entrepreneurship. This suggests that high level of education attainment increases women's potentials and capacity to own and successfullymanage a business.
\end{abstract}

Keywords: Education attainment, Entrepreneurship, Women, Managing business, Bunyoro sub-region

DOI: $10.7176 / \mathrm{JAAS} / 76-04$

Publication date:October $31^{\text {st }} 2021$

\section{Introduction}

The relevance of education has been emphasized by a number of international conventions, such as the Universal Declaration of Human Rights (UDHR) and the Programme of Action of 1994, the 1994 United Nations International Conference on Population and Development and recently the United Nations Sustainable Development Goals (SDGs). The UDHR highlights education as one of the key means of empowering women with skills, knowledge, self-confidence and prepare them to participate fully in the development process (UNFPA, 1994). The Fourth World Conference on Women, held in Beijing in 1995, recognized the importance of literacy as an instrument of women's empowerment. Similarly, the United Nations Sustainable Development Goals (SDGs) prioritized education, gender equality, and women's empowerment. The SDGs made known the cardinal role of education in creating a foundation for sustained economic growth. Goal 4 of the SDGs as adopted by the UN Assembly in 2015 is to ensure inclusive and equitable quality education and to promote lifelong learning opportunities for all.

Uganda's commitment to gender equality cannot be underestimated. Article 32(1) of the 1995 Constitution of the Federal Republic of Uganda provides for affirmative action in favour of marginalized groups including women. Uganda is also a signatory to a number of international and regional instruments which lay out a clear foundation for women's empowerment such as the Convention on the Elimination of all Forms of Discrimination against Women (CEDAW, 1979), the Beijing Declaration and Platform for Action (1995), and the Sustainable Development Goals (SDGs). Owing to the country's commitment to education for gender balance and sustainable development, Uganda achieved gender parity in enrollment at primary level in 2014; similarly, female enrollment into secondary schools increased from $46 \%$ in 2008 to $57 \%$ in 2014 , while total female enrollment into tertiary education increased from $38 \%$ in 2002 to $44 \%$ in 2014 . The female primary education completion rate also improved from $44 \%$ in 2008 to $72 \%$ in 2014 . Similarly, the pass rate of female Primary Leaving Examination (PLE) increased from 65.3\% in 2002 to 86.2\% in 2014 (Ministry of Education and Sports, 2016).

Although female education has generally improved in Uganda, women's economic status in the Bunyoro sub-region remains lower in relation to their male counterparts. For example, much as the region had the lowest youth unemployment rates (11.9\%) for persons of 18-30yrs in relation to the other sub-regions of Uganda, proportional computations from the national housing and population census of 2014 reveal that more young females were unemployed in relation to males (Uganda Bureau of Statistics, 2017). For the same age group, less females $(42.7 \%)$ than males (46\%) were working and, $12 \%$ of females owned agricultural land in relation to $35 \%$ 
of males for the young population (Uganda Bureau of Statistics, 2017). This shows a gender discrepancy in education, employment and access to land in Bunyoro sub-region. The study therefore examined the impact of education attainment women's desire and capacity to venture into entrepreneurship in Bunyoro sub-region, Uganda

\section{Theoretical Framework}

The study was guided by the Human Capital Theory, which emerged in the 1960s through the works of Theodre Schultz in 1962. The theory contends that education enhances an individual's productivity, bargaining power and earning in the labor market. The theory considers educationas an investment that requires collective effort of individuals, private organizations and national governments. From the private investment perspective, education enhances lifetime earnings, access to better paying jobs, and minimizes prolonged periods of unemployment. On the public investment perspective, it promotes growth through increased productivity, health, and social development (Wahrenburg andWeldi, 2007). The theory holds that education enhances an individual's efficiency and productivity skills, which in return increases the earnings of that individual in the labor market and also his/ her ability to establish and manage own business. The level of education and wages are directly related because education attainment enriches the skill of an individual laborer and enables him/ her to efficiently use modern technology (Tan, 2014). In addition, the theory stipulates that formal education is the major prerequisite for improving a country's production capacity because education has the ability to tap into one's innate ability before or during employment, and on the job as well (Tan, 2014). In any case, the theory perceived education attainment as key to a productive population.

The twenty-first century has witnessed the transition from production economy to knowledge economy, changing the manner in which assets are viewed in organizations (Rothaermel, 2012). Traditionally, a firm's physical assets were believed to have direct effect on its economic success, however in today's world, assets influence a relatively small part of an organization's income growth and overall success. From a strategic management perspective, physical resources grant little advantage to organizations since they can be bought and sold on the open market (Rothaermel, 2012). In a knowledge economy, it is the intangible abilities and skills of the workforce and the knowledge inbuilt within organizational structures and processes that contributes to the knowledge capital of an organization (Brush and Cooper, 2012; Mahoney and Kor, 2015).

It is no wonder then that today, the human capital theory has globally influenced the education policy discourse. At supranational levels, for instance within the OECD and the European Union, and within national education systems, the Human Capital Theory depicts education as an "investment" with returns both to individuals and the State in terms of pay and economic growth respectively (Gillies, 2017). Studies have investigated whether education attainment can contribute significantly to the production of overall output in an economy. Trostel et.al., (2002), reveals that individuals with high education tend to have better employment than those who are less educated. Similarly, Olaniyan and Okemakinde (2008) asserts that education has a high potential of improving the production capacity of a population. For example, the higher productivity levels of the Northern bloc of nations when compared with the Southern counterpart could be attributed to higher level of education attainment in the Northern bloc. Additionally, Olaniyan and Okemakinde argues that there is a correlation between higher education level of a population and the State'spropensity for economic growth and stability.

The Human Capital Theory has been largely used to address the question of returns on investment in education and training (Becker, 1994). Barca (2009) postulates that expenditure on education should be treated as an investment and not as a consumer item. According to Uganda Bureau of Statistics, (2017), education is the principal mechanism for developing human knowledge in the developing nations, thus, education is an investment that not only impacts knowledge and skills to individuals, but also values, ideas, attitudes and aspirations which contributes to the nation's development (Uganda Bureau of Statistics, 2017). Barro and Lee (2010) estimates that increasing average years of schooling by one year increases per capita GDP from $1.7 \%$ to $12.1 \%$. Overall, the human capital theory holds that education is anessential tool for human development and the capacity to be successful in the labour market and perhaps entrepreneurship.

\section{Methodology}

The study adopted a descriptive correlation research design, primarily to determine the relationships between education attainment and women entrepreneurship in Bunyoro sub-region of Uganda. The mixed methods approach was used in data collection. A sample size of 365residents of Bunyoro participated in the study. While 365respondents were sampled for quantitative data, 15 key informants were interviewed for qualitative data. The respondents were sampled from the five districts that make up Bunyoro sub-region, which includes: Buliisa, Kibaale, Hoima, Kiryandongo, and Masindi districts - see figure 1, below.Quantitative data gathered from the field were analyzed using descriptive and inferential statistics, while qualitative data was analyzed using the content analysis method. 
Figure 1: Representation of Respondents by District

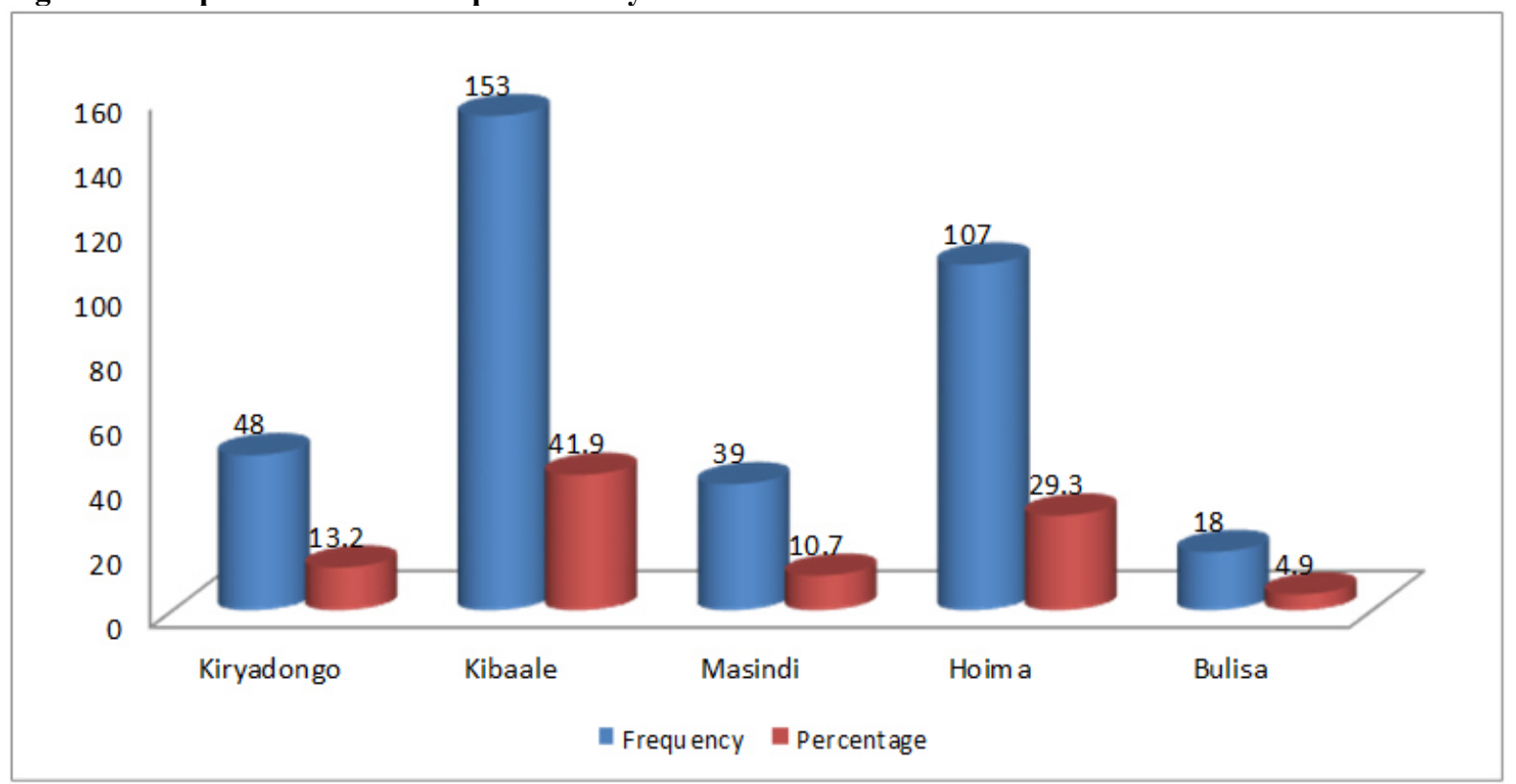

\section{Source: Field Research (2021)}

Figure1 above shows that $48(13.2 \%)$ of the respondents were from Kiryandongo, $153(41.9 \%)$ from Hoima, 39 (10.7\%) from Masindi, 107 (29.3\%) from Kibaale and 18 (4.9\%), from Buliisa. The respondents were proportionally sampled based on the population of the different districts. For example, Hoima has the biggest population, hence the highest number of respondents.

\section{Review of Related Literature}

Entrepreneurship refers to the act of setting up a new business or reviving an existing business so as to take advantage from new opportunities (Bhardwaj et al., 2011). Cantillon (1735) describes an entrepreneur as a person who pays a certain price for a product to resell it at an uncertain price, thereby making decision about obtaining and using resources while consequently assuming the risks of enterprise. Women entrepreneurship is an act of business ownership and business creation that empowers women economically, increase their economic strength as well as position in the society (Despande, 2009). A woman entrepreneur is an adult female who owns and runs an enterprise, especially a commercial one, often at personal financial risks (Bhuvaneshwari, 2013). Also, a woman entrepreneur can be described as a person who accepts challenging role to meet her personal needs and become economically independent.

The concept of female entrepreneurship in its most basic terms is associated with women-owned and operated companies/ businesses. On the other hand, it can be viewed as the number of firms in an economy in which a woman holds more than 50 per cent ownership stakes (OECD, 2019). In a broader perspective, it encompasses the role women play in establishing business ventures as single founders or as co-founders, and their active engagement in the day-to-day running of businesses. Thus, a woman entrepreneur is someone who "has started a business alone or with other women, or someone who is a principal in a family or partnership business, or a shareholder in a publicly-held company (ibid). The concept of women entrepreneurship has gained significant attention due to its visible impact in wealth creation and employment generation. It has a super importance role for accelerating economic growth both in developed and developing countries. It promotes capital formation and wealth creation, reduces unemployment, poverty and offers a pathway for a prosperous life (Bhardwaj, 2011).

Studies of female entrepreneurs in developing countries are still relatively few compared to those in developed countries (Brush and Cooper 2012; Link and Strong, 2016). This is probably because entrepreneurship was historically a male dominated activity (Saridakis, Marlow andStorey, 2014), and an awareness of the importance of female entrepreneurship has only relatively recently been highlighted (Moses et al. 2016). There is a growing literature on the relationship between education attainment and entrepreneurship. Van Der Sluis et al (2008) reveal that education is vital for entrepreneurs because it creates high-quality human capital and forms positive attitudes towards entrepreneurship. This implies that education creates human resources that is needed to run an efficient entrepreneurship. Similarly, Gakidou et al. (2010) argues that attaining a higher education, enhances women's knowledge and skills that are vital for owning and overseeing a business operation. In the same light, Meunier et al, (2017) posits that educational attainment is proportionally 
related to women participation in entrepreneurship. The authorshighlighted that economies with higher female education attainment levels usually have higher numbers of women entrepreneurs at the level of both limited liability companies and sole proprietorships.

According to Global Entrepreneurship Monitor (GEM), (2012) women owned business have grown in number than male-owned businesses by 1.5 times. Over the past two decades, Uganda has witness a significant growth in the number of women-owned businesses. Statistics shows that in Uganda, the women to men owned business has experienced growth of 236percent for women and 153 percent for men. Since 2001, the proportion of women-owned enterprises has increased by 19percent. However, GEM observed that the survival rates of women owned businesses past 42 months is lower than that of men (GEM, 2012); and they have significantly lower percentages of businesses with employees than men at 38percent versus 55percent for men (Kelly et al., 2012). While women entrepreneurs are less likely to have employees than their male counterparts, they are more likely to hire women (GEM, 2012). With this in mind, it is evident that the empowerment of women through active participation in entrepreneurship will produce a ripple effect in terms of women empowerment. If there are more women entrepreneurs, there is a chance that they will employ more women in their business and thus empower more women.

The literature review shows that education is 'fundamental to human capabilities that lie at the heart of development' (Todaroand Smith, 2012, p. 359). It is indicated that education has a positive influence on selfefficacy and self-confidence. It increases one's chances of starting a business and the ability to adjust to the dynamic business environments (Kelly et al., 2015, p. 30). Several scholars have shown that educational attainment is positively correlated with women's self-employment (Kyler et al., 2013; NaguibandJamali, 2015), gender empowerment (Wilhelm and Wilhelm, 2011), and sustainable development (Shah andSaurabh, 2015). Furthermore, Dickson, Solomon, and Weaver (2008) found that the higher the average education level in a country, the higher the rates of selection into entrepreneurship.

Conclusively, female entrepreneurship represents an essential source of economic growth, innovation, job creation and poverty reduction. However, due to the existence of gender inequality in education, women's entrepreneurial potential and their contribution to economic development are hampered. Many developing countries exhibit large gender-based disparities in the accessibility of education, whereby girls and women have limited access to formal training and largely lack legal mechanisms which could allow them to effectively enforce their right to education. Gender gap in education restricts women's knowledge and skill-set and thus creates an unequal playing field for male and female entrepreneurs, with the later carrying less human capital and having less entrepreneurial propensities compared to their male competitors. The disparity in formal training, combined with the existence of a gender-based discriminatory institutional and social framework in some parts of the world, creates significant impediments to the number and success of female entrepreneurs.

\section{Presentation of Findings}

Table 1 shows the results of the mean ratings and standard deviations of the responses obtained from respondents using questionnaires. Table 2, presents regression analysis of the study variables - education attainment and women entrepreneurship. Also, the section presents excerpts from the interviews conducted with key informants.

Table 1: Descriptive statistics showingthe relationship between education and women entrepreneurship

\begin{tabular}{|l|c|c|}
\hline $\mathbf{N}=\mathbf{3 6 5}$ & $\operatorname{Mean}(\overline{\mathbf{x}})$ & $\operatorname{Std}$. Deviation(s) \\
\hline $\begin{array}{l}\text { More educated women likely to start and own business than those } \\
\text { without education }\end{array}$ & 3.90 & .806 \\
\hline Women entrepreneurial success is constrained by lack of education & 4.32 & .811 \\
\hline Lack of education affects women'scapacity to access the market & 3.86 & .811 \\
\hline Lack of education affects women'scapacity to mobilise start-up capital & 4.56 & .719 \\
\hline
\end{tabular}

Table 1 above shows that educations has a significant impact on women entrepreneurship in Bunyoro subregion. Data suggest that women with education are more likely to start own business than those without an education. Also, women without education finds it more challenging to access market and capital needed to start up a business. 
Table 2: Correlation Analysis Between constructs of Education Attainment and Women Entrepreneurship

\begin{tabular}{|c|c|c|c|c|c|c|c|}
\hline \multirow{3}{*}{$\begin{array}{l}\text { Model } \\
\text { Technical } \\
\text { knowledge }\end{array}$} & \multicolumn{2}{|c|}{$\begin{array}{l}\text { Unstandardized } \\
\text { Coefficients }\end{array}$} & \multirow{2}{*}{$\begin{array}{l}\text { Standardized } \\
\text { Coefficients } \\
\text { Beta }\end{array}$} & \multirow[b]{2}{*}{$\mathbf{T}$} & \multirow[b]{2}{*}{ Sig. } & \multicolumn{2}{|c|}{$\begin{array}{l}95.0 \% \text { Confidence } \\
\text { Interval for B }\end{array}$} \\
\hline & B & Std. Error & & & & $\begin{array}{l}\text { Lower } \\
\text { Bound }\end{array}$ & $\begin{array}{l}\text { Upper } \\
\text { Bound }\end{array}$ \\
\hline & 1.603 & 0.152 & 0.489 & 10.557 & 0.000 & 1.304 & 1.901 \\
\hline $\begin{array}{l}\text { Interpersonal } \\
\text { competence }\end{array}$ & 0.979 & 0.167 & 0.287 & 5.845 & 0.000 & .649 & 1.308 \\
\hline $\begin{array}{l}\text { Cultural } \\
\text { competence }\end{array}$ & 0.656 & 0.174 & 0.186 & 3.762 & 0.000 & .313 & .998 \\
\hline
\end{tabular}

a. Dependent Variable: entrepreneurship

*. Correlation is significant at the 0.05 level (1-tailed).

As shown in table 2 above, educational attainment was examined under three headings: technical knowledge, interpersonal competence and cultural competence. Table 2 shows that the relationship between technical knowledge and entrepreneurship is positive and significant (sig.0.00, p-value $<0.05)$ which suggests that women entrepreneurship will increase with an increase in technical knowledge. The findings also show that there is a statistically significant correlation between interpersonal competence and entrepreneurship (sig. 0.00, p-value $<0.05$ ). This implies that an increase in interpersonal competence will correlate an increase in women entrepreneurship. Furthermore, the results show that cultural competence has a statistically significant relationship with entrepreneurship (sig. $0.00, \mathrm{p}$-value $<0.05$ ). The results therefore confirm that education has a significant positive relationship with women entrepreneurship. Thus, a high level of education attainment increases women's potentials and capacity to own and manage a successful business.

The findings of the quantitative data were corroborated by that of qualitative data. The key informants were asked: What are the challenges faced by women in starting their own business in Bunyoro Sub-region? Below are some of the excepts from their responses.

The main challenge I see is capital. As you know business requires capital and in most cases the women of Bunyoro lacks the needed capital to start a business. Apart from fiscal cash, they lack education, which makes it difficult for them to understand the process of getting a business loan from the bank. In fact, due to lack of education, many of the women considers bank loan as a life bondage. Apart from that, they lack assets, which can be used to source for capital. For example, if you want a business loan, the banks and money lenders usually require an asset as collateral before aloan application is approved, of which if the applicant don't have, they will deny the application. In Bunyoro, the most common form of collateral is land, unfortunately many of Bunyoro women rarely own land. This combined with lack of education hampers women's capacity to start a business of their own in Bunyoro(Hoima, 14/12/2020).

For me, I can see two major problems: One is that most women in Bunyoro did not go to school, making it difficult for them to manage a business successfully. The other problem is that women in Bunyoro don't have startup capital for business. Many of them rely on their husband for daily feeding and upkeep, so they can't afford to start a business, unless where their husband is ready to finance the business (Buliisa, 17/12/2020).

The above answers evidently show that women have challenges in starting a business in Bunyoro. The major challenges identified by the key informants include illiteracy, most Bunyoro women did notgo to school and therefore have limitations in skills needed to manage a business successfully. Besides, they lack the needed capital to start a business. In summary, illiteracy and lack of capital are the major factors affecting women entrepreneurship in Bunyoro sub-region. Overall, the study findings reveal that education influences women's ability, skills and capacity to own and manage a business in Bunyoro sub-region of Uganda.

\section{Conclusions}

The study investigated the relationship between education attainment and women entrepreneurship in Bunyoro sub-region. In doing so, education attainment was measured as technical knowledge, interpersonal competence and cultural competence. Based on the empirical data obtained during the study, education attainment has a significant positive impact on women entrepreneurship in Bunyoro sub-region. Education influences women's ability and capacity to own and manage a business successfully. It offers women opportunity to access capital and gain skills needed for the day-to-day management of a business. Thus, education attainment is the bedrock of women's entrepreneurship venture and success of the broader concept of Women economic empowerment. 


\section{References}

Barca, V., Brook, S., Holland, J., Otulana, M. and Pozarny, P. (2015). Qualitative Research and Analyses of the Economic Impact of Cash Transfer Programmes in Sub-Saharan Africa. Synthesis Report. From Protection to Production (PtoP) Report. Rome: FAO

Becker, G. S. (1994). Human Capital: A Theoretical and Empirical Analysis with Special Reference to Education, $3^{\text {rd }}$ Edition. Chicago: The University of Chicago Press.

Bhardwaj, G. N.; Parashar, S.; Pandey, B. andSahu, P. (2011). Women Entrepreneurship in India: Opportunity and Challenges. The Journal of Management. 2(7), pp. 13-26

Bhuvaneshwari, P. and Annapoorani, D. (2013). Prospects and Challenges of Women Entrepreneurship with Specific Reference to Dalits. International Journal of Research in Commerce and Management. 4(1), pp. 18.

Brush, C.G. and Cooper, S.Y. (2012). Female entrepreneurship and economic development: An international perspective. Entrepreneurship and Regional Development, 24(1), pp. 1-6.

Cantillon, Richard (1959). Essay on the Nature of Trade in General. London: Frank Cass and Co.

Deshpande, S. and Sethi S. (2009). Women Entrepreneurship in India Problems, Solutions and Future Prospects of Development. International Research Journal 2(9-10), pp. 13-17.

Dickson, P. H., Solomon, G. T., and Weaver, K. M. (2008). Entrepreneurial selection and success: does education matter? Journal of Small Business and Enterprise Development, 15(2), pp. 239-258

Gakidou, E., K. Cowling, R. Lozano, and Murray, C. J. (2010). Increased Educational Attainment and its Effect on Child Mortality in 175 Countries Between 1970 and 2009: A Systematic Analysis.The Lancet, 376 (9745): 959-974.

Gillies, D. (2017). Human Capital Theory in Education. In Peters M.A. (eds.), Encyclopaedia of Educational Philosophy and Theory. Singapore: Springer.

Global Entrepreneurship Monitor (2017). GEM 2016/2017 Women's Entrepreneurship Report. London: GEM.

Mahoney, J. T and Kor, Y. Y. (2015). Advancing the Human Capital Perspective on Value Creation by Joining Capabilities and Governance Approaches. Academy of Management Perspectives 29(3), pp. 296-308.

Rothaermel, F. T. (2012). Strategic management concepts and cases. New York: McGraw-Hill.

Saridakis, G.; Marlow, S. and Storey, D.J. (2014). Do different factors explain male and female self-employment rates? Journal of Business Venturing 29(3), pp. 345-362.

Tan, E. (2014). Human Capital Theory: A Holistic Criticism. Review of Educational Research 84(3), pp. 411445

UNFPA (2002). State of World Population 2002: People, Poverty, and Possibilities. New York: UNFPA.

Todaro, M. P., and Smith, S. C. (2012). Economic Development. Boston: Addison-Wesley.

Kelly. D., Brish. C., Greene. P.; and Litovsky, Y. (2012). Global Entrepreneurship Monitor 2012 Women's Report. Wellesley, MA: Babson College.

Kyler, K., Nielsen, S. L., andEvald, M. R. (2013). Women's self-employment: An act of institutional (dis) integration? A multi-level, cross-country study. Journal of Business Venturing, 28(4), 474-488.

Link. A. N and Strong. D. R (2016). Gender and Entrepreneurship: An Annoted Bibliography. Foundations and Trends in Entrepreneurship, 12(4), pp. 287-441.

Meunier, F., Krylova, Y., Ramalho, R. (2017). Women's Entrepreneurship. How to Measure the Gap between New Female and Male Entrepreneurs? Policy Research Working Paper Series 8242, The World Bank.

Moses. C. L., Olokundun. M. and Falola. H (2016). A Review of the Challenges Militating against Women Entrepreneurs in Developing Nations. Mediterranean Journal of Social Sciences, 7(1), pp. 64-69.

Naguib, R., and Jamali, D. (2015). Female entrepreneurship in the UAE: A multi-level integrative lens. Gender in Management: An International Journal, 3(2), 135-161.

OECD (2019). "Labour force participation”, in Society at a Glance: Asia/Pacific 2019. Paris: OECD Publishing.

Olaniyan, D.A., and Okemakinde, T. (2008). Human Capital Theory: Implications for Educational Development. Pakistan Journal of Social Sciences, 5(5), pp. 479-483.

Shah, H., andSaurabh, P. (2015). Women entrepreneurs in developing nations: Growth and replication strategies and their impact on poverty alleviation. Technology Innovation Management Review, 5(8), pp. 34-43-

Trostel, P., Walker, I., and Woolley, P. (2002). Estimates of the economic return to schooling for 28 countries. Labour Economics, 9(1), pp. 1-16.

Van Der Sluis, J., M. Van Praag, and Vijverberg. W. (2008). Education and Entrepreneurship Selection and Performance: A Review of the Empirical Literature.Journal of Economic Surveys 22 (5), pp. 795-841.

Wahrenburg, M., Weldi, M. (2007). Return on Investment in Higher Education - Evidence for Different Subjects, Degrees and Gender in Germany. Discussion paper, Goethe University Frankfurt

Wilhelm, P. G., and Wilhelm, J. P. (2011). Gender empowerment, global competitiveness, economic freedom and wealth: Validation studies and implications for sustainable policy. Competition Forum, 9(2), pp. 406412. 